\title{
The Impact of Budgeting and Budgetary Control on the Liquidity Levels of Non Profit making Organizations in Uganda
}

\author{
A Case of Infectious Diseases Institute in Kampala District \\ Article by Bombo Henry Lubega \\ MBA, Texila American University, South Sudan \\ Email: bombohenry@texilaconnect.com
}

\begin{abstract}
This study was conducted using Infectious Diseases Institute (IDI) as the Case study. A sound and effective budgeting system is based upon certain prerequisites/or conditions. Failure to observe and appreciate these essentials will render the budgeting exercise ineffective (Arora, 1995). It was against this background that the study was aimed at examining the effectiveness of IDI budget systems and its impact on the liquidity levels of the Institution.

The respondents were selected using purposive and simple random sampling techniques. Descriptive and Associational research designs were adopted with Data gathered through Questionnaires and interview guides. The SPSS technique was used to establish the relationship between Budgeting systems and liquidity levels.

The major findings from the research study indicated that the budgeting systems used were inapt. It was also revealed that, there exists a positive relationship between Budgeting systems and control and liquidity level. In this respect, it was concluded that though many other factors were pointed out as possible causes of the declining levels of liquidity in the Institution between 2010 and 2014, poor budget systems and budget control strategies were largely held responsible.

Considering the persistent declining liquidity trend, a new approach of budgeting which encourages improvement by eliminating inefficiencies and wasteful expenditure should be adopted.
\end{abstract}

\section{Introduction}

This chapter gives details of the background, problem statement, purpose, objectives, research questions, significance and the scope of the study.

\section{Back ground to the study}

Budgeting is a process involving the planning, in financial terms, of a comprehensive and co-ordinated framework for guiding the periodical acquisition, spending and control of funds in order to achieve the desired financial performance targets. (Pandey, 1996). Accordingly, budgeting is one of the major factors that affect the Liquidity of any enterprise or project, be it private or public. Thus for survival of any organization, management need to embark on effective budgeting and control to effect proper planning and control (Idegwe, 2013)

Liquidity refers to the ability of an organization to meet its short term obligations. In other words, it is the ability of an organization to make funds available on demand at short notice, to cater for its operational demands (Rosenburg, 1983). There are several interested parties in the liquidity of an organization. These include suppliers of goods and services on credit, employees, donors and lending financial institutions. Therefore, any organization that cannot continue to honour its obligations to any of the above stake holders can be declared a sick or bankrupt organization. As Riddel (1995), points it out, there is always need for any organization to maintain a certain degree of liquidity in order to enhance its operations.

Infectious Diseases Institute (IDI) is a Ugandan not-for-profit organization, owned by Makerere University and funded through diverse public and private resources. IDI's mission is to strengthen health systems in Africa, with a strong emphasis on infectious diseases, through research and capacity development. The Institute began life in 2002 with most of its 
key funding coming from Pfizer Inc. Over years, IDI has built a broad funding base with over 80 projects currently in progress. Key funders include; US Centres for Disease Control (CDC), the US President's Emergency Plan for AIDS Relief (PEPFAR), Bill and Melinda Gates Foundation, US National Institutes of Health (NIH), European Union, Government of Uganda (GOU), ELMA Foundation, and many various US Corporations and Universities.

Generally, IDI's funding base has tremendously expanded over years. However, despite all this the institute continues experiencing budget shortfalls. Given this trend of events, its highly questionable whether proper budgetary control techniques are applied. Generally, there is still lack of focus on strategic areas on which the funds got should be prioritized. This trend of events could be attributed to inappropriate budgeting systems and control techniques applied at the institute.

\section{Statement of the problem}

Budgeting has been described as a planning tool for setting a frame work to guide the achievement of the desired performance reflected in the set targets according to Pandey, (1996) \& Hay and Engstron, (1987). Budgets are necessary to prudently manage scarce financial resources and at the same time as means of expenditure authorization, control and evaluation base, Julia (2001). Like any other Organization, Infectious Diseases Institute has a budget system in place and a fully-fledged budgeting team to plan and monitor its budget performance. However, in spite of this, it is evident that for the past four financial years, the Organization continues facing budgetary problems indicated by shortages of funds to finance its key strategic activities. This explains why the institute has had to adopt various stringent approaches in order to continue operating at a break even budget. There was retrenchment of staff from key departments such as Grants \& Contracts, Prevention \& Treatment (PCT), Training, Operations and Research, as well as phasing out of the team that was providing refreshments and tea at the IDI facilities. As such, if the problem continues to exist there are threats that the donor organizations may withdraw its further intentions of funding the institute's operations which may lead to its subsequent closure. It's because of this that the research picked interest in analyzing the effectiveness of IDI's budgeting systems.

\section{Purpose of the study}

The major aim of the study will be to examine the impact of Budgeting and Budgetary controls on the liquidity levels of Non-governmental Organizations in Uganda, a case of Infectious Diseases Institute.

\section{Objectives of the study}

(i) To investigate the appropriateness of the budgeting system used in Infectious Diseases Institute.

(ii) To establish the level and trends of liquidity in the organization

(iii) To establish the relationship between budgetary control and the liquidity levels of the Organization.

\section{Research questions}

(i) How appropriate are the budgeting systems used in the Institution?

(ii) What are the levels and trend of Liquidity in Infectious Diseases Institute?

(iii) What is the relationship between budgeting and the liquidity of Infectious Diseases Institute?

\section{Scope of the study}

\section{Subject scope}

The study was confined to examining the impact of budgeting and budgetary control on the liquidity level of Infectious Diseases Institute. The study aimed at investigating the budgeting 
systems used and evaluating strategies used towards budgetary control so as achieve the targeted liquidity levels in the Organization.

\section{Geographical scope}

The study was carried out at Infectious Diseases Institute which is located at Mulago Hospital Complex, in Kampala Uganda, East Africa.

\section{Time scope}

In terms of time scope, the study covered the liquidity performance of the Organization for the financial periods July 2010 to June 2014

\section{Significance of the study}

It is hoped that the study will be useful in the following ways;

(i) This research will help the management of infectious Diseases Institute to appreciate the benefits of applying proper budget control systems.

(ii) The study will help the donor community to appreciate the impact of budgeting on the effectiveness of their disbursed funds.

(iii) The study is intended to add to the existing literature on budgeting and liquidity performance, to help future researchers in similar fields of study as a reference.

\section{Literature Review}

\section{Introduction}

This chapter provides a review of the existing literature by other researchers/or scholars towards the variables under study, that is budgeting and liquidity. It also tries to explain in detail the different stages of budgeting, the major participants in the budgeting process and the major approaches of budgeting. The major liquidity indicators are also clearly highlighted, plus a review of the relationship between budgeting and liquidity.

\section{Budgeting}

\section{Budgeting defined}

In an attempt to explain what a budget and budgeting is, a number of definitions have been put forward by different Authors and scholars. These include;

A budget is a quantitative expression of the goals and objectives an organization wishes to achieve and the costs of attaining those goals (Drury, 1992; Lucy, 1996).Budgets are part of a larger system that involves setting goals and objectives, considering alternatives and ensuring that the organization efforts and activities are directed towards achieving the slated objectives.

Horngren et al (1993) defined a budget as; "a formal quantitative expression of a plan that provides a bench mark against which to measure actual performance. In other words, a budget is a quantitative plan of action expressed in monetary terms and is used as a tool to control resources.

According to Stoner et al (1996), a budget is a formal quantitative statement of resources set aside for carrying out planned activities over a given period of time.

Pandey (1996) describes budgeting as a; "process of preparing in financial terms, a meaningful time based course of action for achieving management expectations, that is to say; it provides a frame work for implementing a planned course of action using the available resources and therefore provides a means of controlling the performance of individual units within an Enterprise, and of the Enterprise as a whole, so that the desired results are achieved.

According to Balunywa (1997), budgeting is referred to as; the establishment of budgets relating to the responsibilities of executives to the requirements of policy and the continuous comparison of actual results with budgeted results. The objective of that policy is to provide basis for revision.

To crown it up all, the Chartered Institute of Management Accountants, London, defines a budget as, "a plan quantified in monetary terms, prepared and approved prior to a defined 
period of time, usually showing planned income to be generated and/ or expenditure to be incurred during that period". This implies that a budget is a plan of management intentions of attaining specified objectives.

N.B The process of preparing and using budgets to achieve the specified organizational goals and objectives is what is referred to as budgeting.

However, in trying to analyze all the above definitions, there is one critical observation to note, that is, all the cited authors are very general. They do not specify any type of organization nor project where budgeting can help set goals and objectives to guide the achievement of the desired targets.

This study attempts to scale their observations down to Infectious Diseases Instituteestablishing whether budgeting conducted in the institution sets any objectives and targets in order to guide the achievement of its desired Liquidity level.

\section{Appropriateness of the budgeting process (system) conducted}

According to the management accounting theory, though budgets are important tools in guiding management to focus on organizational goals and objectives, they may not succeed if an effective budget process is not put in place. Therefore, an effective budget process is much more important than having budgets on paper (Drury, 1992)

At this point, it is therefore imperative to discuss the major stages of the budget process, the major players in the process and how if followed effectively may lead to successful formulation and implementation of budgets in an organization.

\section{Stages in the budgeting process}

The budgetary process involves a series of sequential stages which need to be co-ordinated so as to achieve the final budget. Though many scholars have attempted to analyse these stages, (Drury, 2000); seems to have analysed them in a more logical way. According to him, the stages of budgeting include the following;

\section{Communicating details of the budget policy}

The need to prepare budgets and the needed guidelines is communicated to those people responsible for the preparation of the budget. Management must ensure that policy effects are made aware to the staff participating in budget making (Drury, 2000)

\section{Determining the factors that restricts performance}

Such factors are also known as; 'Principle budget factors'. They represent the resources that constrain the productive capacity of the firm. Management should strive and identify the factors that restrict performance, since such factors determine the point at which the annual budgeting process should begin (Arora, 1995) Examples of limiting factors in an institution may include; space (such as lecture rooms), labour hours (especially those on part time basis) e.t.c.

Proper identification of the budget factor enables management to allocate resources in the most efficient manner (Biggs and Benjamin, 1990).

\section{Preparation of budgets}

According to Drury, 2000; the managers who are responsible for meeting the budgeted performance should prepare the budget for those areas for which they are responsible. The preparation of budgets should be a 'bottom - up' process. All these budgets are integrated and co-ordinated into a master budget.

\section{Negotiation of budgets}

The lower cadres who originate sectional budgets usually present them to their immediate supervisors. These supervisors usually negotiate the budgets with their subordinates or with their supervisors in their lines of command (Arora, 1995). 


\section{Coordination and review of budgets}

The independent budgets prepared by different sections or departments should be reviewed and reconciled to ensure that they address the same objectives (Hongren, 1993). This examination may indicate that some budgets are out of balance with other budgets and need to be adjusted so as to enhance compatibility of the budget with other conditions, constraints and plans that are beyond a manager's knowledge or control.

\section{Final acceptance of the budgets}

After the prepared budgets have been harmonized and accepted, they are integrated into a master budget. According Kamukama Nixon, (2009); a master budget is a comprehensive plan which covers all operational budgets which include sales budget, production, labour cost e.t.c. The master budget also covers the forecasted statement of comprehensive income, statement of financial position and cash flow statement.

\section{Budget review}

This covers a control stage which must be carried out in order to establish whether the set objectives or targets are being achieved. The review exercise also involves taking appropriate actions to address any anomalies (Drury, 2000).

However, any sound and effective budget process is based upon certain pre-requisites. These conditions must exist, absence of which will undermine to a larger extent, the effectiveness of a budget system in any organization. Amanya (1999), pointed out the importance of the following key conditions; Top management support, Employee participation in the budget process and Managerial use of budget information in the budgeting process.

\section{These conditions are briefly discussed her below;}

\section{The role of top management in support of the budget process}

Arora (1995) asserts that, top management provides an impetus and direction to the budgeting process. According to Amanya (1999), top management support in the budgeting process may take the following forms;

\section{Establishing clear and realistic goals}

Budgeting will not succeed if the goals to be achieved are not clear. It is therefore essential for top management to ensure that objectives and goals have been properly laid down and communicated objectively in the budgets (Arora, 1995).

\section{Communicating details of the budget policy}

According to Drury (1992), it is top management responsibility to communicate the policy effects of the corporate long-term plan to those responsible for preparing the current year's budget.

\section{Initiating and providing budget procedures and guidelines}

To ensure that budget process works out effectively, it is important that suitable administrative procedures are established and then circulated to all individuals who are responsible for preparing the budgets (Morden, 1986).

\section{Initial preparation of budgets}

Budget preparation should essentially be a bottom-up process. Managers and their subordinates who are responsible for meeting the budgeted performance should prepare the budgets for the areas for which they are responsible (Stoner, 1996). 
South American Journal of Management

Special Edition 2016

\section{Co-ordination of various departmental budgets}

Whereas departmental managers should prepare budget estimates, top management is charged with the responsibility of co-ordinating different departmental budgets and finally approving them (Drury, 2000).

\section{Continuous budget monitoring and review}

According to Drury (1992), the budgeting process should be seen as a continuous dynamic process. Olive et al (1995) argues that, top management must ensure that clear and comprehensive reports are made frequently and sent to the appropriate budgets to enable them identify items that may not be proceeding according to plan and to investigate into the causes of the differences.

\section{Employee participation in the budgetary process}

Olive et al (1995) pointed out that budgets will not achieve their purpose unless they are accepted by the users. Hofstede further argues that acceptance and commitment to the budget targets can be achieved by ensuring employee participation in the budget setting process.

\section{Outcome/results of employee participation}

The roles of employee participation in achieving budget acceptance are seen below;

Participation improves on the employee attitudes towards the budget System resulting into acceptance of budgets by the subordinates as their own (Pandey, 1996).

According to Amanya, (1999); Participation leads to improved communication and better budget standards. This results into better budget monitoring and review.

Participation in budget setting will decrease on the likelihood of Information distortion and manipulation (Miller, 1996).

It promotes understanding among members of management of that Organization and their workers hence reducing trivial problems ( Dr. Rao, 1997).

\section{Managerial use of budgetary information}

Budgeting is part of management information system that provides managers with useful score keeping and attention directing information to enable them to manage their responsibility centers more efficiently (Olive et al, 1995).

\section{Different approaches (techniques) to budgeting}

Different organizations use different approaches (techniques) of budgeting. The choice of budgeting technique adopted by any organization depends on the existing procedures and guidelines as well as on the ease with which a manager finds in using the technique. The major approaches to budget setting and their associated merits and shortcomings are discussed below;

\section{Incremental budgeting}

Under this approach, budgets are prepared using the previous budget as a reference point. According to Fozzard .A, (2001); incremental budgeting involves making adjustments to the previous budget figures to cater for inflation and changes in other variables e.g. Exchange rates. Only additional items requested are scrutinized.

This approach traditionally gained a lot of support because it is fairly easy to prepare and saves the budget a lot of time in budget preparation (Drury, 2000).

However, according to Amanya, (1999); the major draw backs to this approach are that previous years' inefficiencies are perpetuated and also discourages innovation and creativity to budget making. 


\section{Zero-Based Budgeting (ZBB)}

ZBB is a formalized approach of budgeting for the activities of an organization, as if each activity was performed for the first time (Morden, 1986). The technique starts the financial a year fresh. It doesn't base on the previous financial years' budget.

\section{The major merits of this approach include the following}

It encourages the identification and removal of obsolete operations from the budget. In so doing, previous financial years' inefficiencies are always eliminated in the system. This results into efficient allocation of resources (Grace C.E, 1964).

It ensures continuous re-evaluation of the activities of the organization to ascertain that they are absolutely necessary for the organization, those activities that are of no value find no place in the forth coming budget even though they might have been an integral part of the past budgets (Arora, 1995).

Staff and managers will have a thorough knowledge of the operations and activities. Since the approach doesn't base on the previous financial years' budget, mangers are always forced to look for alternative ways of providing the functions which increases motivation (Drury, 2000).

\section{However, the technique has also got some challenges;}

It is a costly exercise because the budget process is re-started each financial year. It also requires skilled manpower to draw the decision packages and rank them. However, it is normally difficult to get such skilled personnel, who are also expensive to maintain (Amanya, 1999).

It imposes a heavy burden to the budget making process (Drury, 1992). This is because it involves identifying and scrutinizing the various activities to be performed before they are finally considered as necessary for the organization.

In addition, the approach is likely to be resisted by those who fear that their programmes would be jeopardized by a system that subjects them to annual scrutiny (Bellis J, 1991).

Despite the above challenges, ZBB approach has been embraced by most organizations worldwide because it is more forward looking as opposed to (the method of extrapolation of past activities and costs a common feature of incremental based budgeting (Suver and Brown, 1977).

\section{Activity Based Costing (ABC) approach}

According to Balunywa, (1997), the major purpose of budgeting is to decide how much resource is needed in an organization, to establish the necessary capability to meet current and future organizational goals and objectives.

In this regard, a new approach to budgeting, $\mathrm{ABC}$ approach has been proposed by a number of authors and researchers (Belliner and Develin, 1991; Bellis, 1992; Brown, 1994). The ABC approach works on the premise that; it is the activities that drive costs and those activities should be identified with cost pools. The budget is therefore prepared based on the activities to be earned out by each cost centre.

\section{The approach involves different steps which include the following;}

(a) Identifying the various departments in the organization for which the budget is to be prepared and analyze its major activities for which cost drivers may be identified.

(b) Determining the budget cost of resources to be used by each of the activity.

(c) Deciding on the future activity levels and work backwards to determine the required resources and inputs.

(d) Taking action to adjust the capacity of resources and address the resource short falls.

\section{The approach has got the following merits;}


It takes into account the impact of the activity levels on the cost of resources. In this case, the budget setting will be more rational as it is based on demand side (i.e. consumption) rather than just the supply side data (Bellis, 1992).

Activity unit cost allows easy analysis of cost trends over time and interdepartmental comparisons. This enables easy performance assessment (Lucy, 1992).

$\mathrm{ABC}$ approach leads directly to total quality management by relating the cost of an activity to the level of output.

Efficiency of use of resources is enhanced because each service consumed will attract a consumption- related cost. Therefore the issue of common or over head cost evaluation will also be handled (Morden, 1986).

\section{The $\mathrm{ABC}$ approach has also got some short comings as discussed below;}

According to Pandey, 1996; the cost of obtaining and interpreting the activity based information may be high.

A single cost driver mayn't be suitable to explain the behaviour of all costs in associated cost pools (Drury, 2000).

Many overheads may not relate to either volume or to complexity and diversity. This makes work cumbersome and complex.

\section{Planning Programming Budgeting (PPB) approach}

According to Fozzard, (2001); this type of budgeting is intended to overcome the difficult under the line item budgets.

\section{It is an approach which involves the following steps;}

a. Establishment of the overall organization objectives.

b. Identify the programme that helps to achieve the objectives.

c. Determine the costs and benefits.

d. Evaluate each programme on cost-benefit analysis.

e. Allocate resources accordingly.

This approach is most applicable in NGOs, CSOs and each programme has projects. However, the major drawback of this approach is that, it involves making subjective judgments.

\section{Importance of budgeting}

Budgets are key elements in an organization's control system. They are designed to assist management in allocation of authority and responsibility, making estimates and plans for the future. Budgets assist in the analysis of the variations between the estimated and actual performance and to develop a basis against which to evaluate the efficiency of operations. In this way, they assist management to take actions that are in line with the organization's goals and objectives (Drury, 1992).

\section{The major importance's of budgeting are briefly discussed below;}

\section{Planning}

By their nature, budgets are essentially formalized plans of management's intended action and desired results. Planning is an essential function of managers to accomplish goals. Stoner (1996) argues that planning reduces uncertainty and provides direction to employees by determining the course of action in advance. By determining well in advance what should be done, what individuals/units are to assume responsibility and be held accountable, budgeting provides an orderly way to proceed in attaining organizational goals (Grace C.E, 1964).

Another key aspect of budgeting as a planning tool is that it encourages managers to anticipate problems before they arise, thus minimizing incidences of hasty decisions that are made on the spur of moment, based on expediency rather than reasoned judgment. In support 
of this, Drury (1992) argues that budgets prevent management from relying on adhoc or uncoordinated planning that may be detrimental to the performance of the organization.

\section{Co-ordination}

A budget serves as a vehicle through which actions of the different parts of an organization can be brought together and reconciled into a common plan. As Drury (1992) points out, without any guidance, managers may each take their own decisions, believing that they are working in the best interests of the organization which mayn't be the ease.

Therefore, through an effective budgetary process, the activities of the various departments are co-ordinated. This enhances unity and instills a strong sense of responsibility in each employee towards attainment of common goals.

\section{Control}

Once a comprehensive and co-ordinated plan of action has been formulated, it should be communicated to those responsible for implementation. In this respect, a budget assists managers in controlling the activities for which they are responsible. This is because a continuous comparison of the actual results with the budgeted amounts assists managers to ascertain which costs do not conform to the original plan of their attention for their attention.

Olive et al (1995) and Drury (1992) argue that an effective budget process enables management to operate a system of "Management by Exception". This is a situation where managers' attention and efforts are concentrated on significant deviations from the expected results. In this way, managers are likely to identify the causes of deviations and initiate appropriate control action to remedy the situation.

\section{Communication}

Communication is an essential element in organizations to keep all parts fully informed of the goals, objectives, policies and constraints to which the organization is expected to conform (Arora, 1995; Lucy, 1996). Budgets are an important channel for communicating such information that will enable managers in different parts of the organization to coordinate their activities more efficiently.

Horngren (1987) argues that; the budgeting process is a vehicle through which top management communicates goals or expectations to ensure proper co-ordination of the various activities in the organization.

\section{Performance Evaluation}

It is common practice to attempt to assess the performance of an individual employee/or a manager by a comparison of the budgeted and actual results for his area of responsibility in the organization. Amanya (1999) argues that; the existence of a budget standard can act as a target to be aimed for. In this respect, a budget may be used to serve as a yard stick for evaluating employee performance (Pandey, 1996) and inform them of how well they are performing in meeting the previously set targets.

\section{Major constraints to budgeting}

Excessive emphasis on budgeting may result in attempts by lower level management and employees to manipulate and provide mis-leading results about costs and revenues (Briers et al, 1990).

The budget plans are based on estimates. Forecasting cannot be an exact science. Absolute accuracy therefore is not possible in forecasting and budgeting. The strength and weaknesses of budgeting systems depends to a large extent on the accuracy with which the estimates are made (Biggs, C and Benjamin, 1990).

Budgets are developed around existing organizational structures, which may be inappropriate for current conditions (Clive, 1995).

Dangers of rigidity. A good budget must be dynamic and continuously deal with changing business conditions. However, most budgets used in organizations exist as well-documented 
plans which are rarely revised to suit changing conditions, hence rendering them meaningless (Drury, 2000).

However, despite the above limitations, what needs to be emphasized is that budgets are very important tools in the operations of any organization. Nevertheless, budgets if properly used are vital tools in planning, monitoring and controlling managerial and overall organizational performance.

\section{Liquidity}

\section{Liquidity defined}

According to the Chartered institute of Accountants, London, Liquidity refers the ability of a company to meet its short term obligations as they due fall. The liquidity position of a firm indicates whether it has sufficient funds to enable it pay its short term financial obligations (Dale, 1999).

According to Riddle (1995), Liquidity is the ability of the company to convert its short term assets into cash and thus enabling it to finance its Short term obligations. Short term, generally, signifies obligations which mature within one accounting year. Short term also reflects the operating cycle: buying, manufacturing, selling, and collecting.

According to Rosenburg (1983), a company that cannot pay its creditors on time and continue not to honor its obligations to the suppliers of credit, services and goods can be declared a sick company or bankrupt company.

Liquidity in terms of financial management is defined as the ability of a person, an organisation or a company to readily and easily obtain cash from its assets in order to meet its obligation or make purchases (Denise L. Evans, J D \& O. Williams Evans, J D ,2007).

According to Kimberly Amadeo and T. Adrain, 2009; Liquidity is defined as financial level of an organisation or a company to spend its planned and budgeted resources and then relate it to the level of investment to acquire its goals.

\section{Measures (Indicators) of liquidity}

According to Rosenburg, (1983); in any given institution, one can understand the liquidity position by analyzing the financial statements (balance sheet) of that institution. The following financial items are required to understand the liquidity position;

Current Assets: - these are assets that are reasonably expected to be converted into cash within one year in the normal course of the business. These include; cash, accounts receivable, inventory, prepaid expenses e.t.c. They are very important to businesses because they are assets that are used to finance day to day operations and pay outstanding debts and cover liabilities without having to sell fixed assets.

Current Liabilities: - these are company's debts /or obligations that are due within one year. These include; accounts payable, accrued expenses, short term debts e.t.c. Essentially, these are bills that are due to creditors and suppliers within a short period of time.

Financial analysts and creditors often use different ratios to determine the liquidity positions of companies.

\section{Liquidity ratios}

Liquidity ratios attempt to measure a company's ability to pay off its short-term debt obligations. This is done by comparing a company's most liquid assets (or, those that can be easily converted to cash), with its short-term liabilities (Conroy, 2005).

In general, the greater the coverage of liquid assets to short-term liabilities the better, as it is a clear signal that a company can pay its debts that are coming due in the near future and still fund its ongoing operations. On the other hand, a company with a low coverage rate should rise a red flag for investors as it may be a sign that the company will have difficulty meeting running its operations, as well as meeting its obligations. (Bech, 1993 and Washam, 1989)

The most commonly used liquidity ratios by financial analysts are discussed here below; 


\section{Current ratio}

This is the most popular financial ratio used to test a company's liquidity position (also referred to as its current or working capital position) by deriving the proportion of current assets available to cover current liabilities ( John Wiley, 2004).

It is obtained by dividing current assets by current liabilities. The concept behind this ratio is to ascertain whether a company's short-term assets (cash, cash equivalents, marketable securities, receivables and inventory) are readily available to pay off its short-term liabilities (notes payable, current portion of term debt, payables, accrued expenses and taxes) (Riddle, 1995).

In theory, if the ratio is high, then the company is generally considered to have good short term financial strength and, if the ratio is low, then the company may have problems meeting its short term obligations (Charles. T, 2004).

\section{Formula:}

$$
\text { Current Ratio }=\frac{\text { Current Assets }}{\text { Current Liabilities }}
$$

\section{Limitations of current ratio as a measure of liquidity}

However, though the current ratio is easy to understand and therefore used extensively in financial reporting, it can be misleading in both positive and negative sense i.e. a high current ratio mayn't necessarily be good, and a low current ratio mayn't not necessarily be bad as the ratio pre-supposes.

Contrary to popular perception, current ratio, as an indicator of liquidity, is flawed because it's conceptually based on the liquidation of all of a company's current assets to meet all of its current liabilities. In reality, this is not likely to occur. Investors have to look at a company as a going concern. It's the time it takes to convert a company's working capital assets into cash to pay its current obligations that is the key to its liquidity. In this respect, current ratio is regarded 'mis- leading' (John Wiley, 2004).

Therefore, when looking at the current ratio, it is important that a company's current assets can cover its current liabilities; however, investors should be aware that this is not the whole story on company liquidity. They should try to understand the types of current assets the company has and how quickly these can be converted into cash to meet current liabilities. This important perspective can be seen through the cash conversion cycle. By digging deeper into the current assets, investors (financial analysts) will gain a greater understanding of a company's true liquidity (Riddle, 1995).

\section{Quick Asset ratio}

According to Conroy, (2005); Quick asset ratio is the measure of a company's liquidity and ability to meet its obligations. Quick asset ratio, often referred to as acid test ratio, is obtained by subtracting inventories from current assets and then dividing by current liabilities. The indicator is more conservative, than the current ratio because it excludes inventory and other current assets, which are more difficult to turn into cash. By excluding inventory, the quick ratio focuses on the more liquid assets of a company. Therefore, the higher the ratio, the more liquid the company is and, the lower the ratio, the less liquid the company is (Riddle, 1995).

\section{Formula:}

Quick Ratio $=\frac{\text { Cash \& Equivalents }+ \text { Short }- \text { term Investments }+ \text { Accounts Receivable }}{\text { Current Liabilities }}$

However, some scholars of financial analysis for example, Washam, (1989) and Beck, (1993); states that when calculating quick ratio, we simply subtracting the inventory figure from the total current assets figure. The logic is that by excluding relatively less-liquid (harder to turn into cash) inventory, the remaining current assets are all of the more-liquid variety. 
Generally, this is close to the truth, but not always because there are some current assets for example; restricted cash, prepaid expenses and deferred income taxes that do not pass the test of truly liquid assets. Thus, using the shortcut approach artificially overstates the company's more liquid assets and inflates its quick ratio.

The basics and use of this ratio are similar to the current ratio in that it gives users an idea of the ability of a company to meet its short-term liabilities with its short-term assets. Another beneficial use is to compare the quick ratio with the current ratio. If the current ratio is significantly higher, it is a clear indication that the company's current assets are dependent on inventory.

\section{Limitations of the Quick Asset ratio as a measure of liquidity}

While considered more stringent than the current ratio, the quick ratio, because of its accounts receivable component, suffers from the same deficiencies as the current ratio - albeit somewhat less. In brief, both the quick and the current ratios take a liquidation of accounts receivable and inventory as the basis for measuring liquidity. While theoretically feasible, as a going concern a company must focus on the time it takes to convert its working capital assets to cash, that is the true measure of liquidity. Thus, if accounts receivable, as a component of the quick ratio, have, let's say, a conversion time of several months rather than several days, the "quickness" attribute of this ratio is questionable (John Wiley, 2004).

Investors need to be aware that the conventional wisdom regarding both the current and quick ratios as indicators of a company's liquidity can be misleading.

\section{Cash ratio}

The cash ratio is an indicator of a company's liquidity that further refines both the current and the quick ratio by measuring the amount of cash; cash equivalents or invested funds there are in current assets to cover current liabilities (Kimberley. A, 2009)

\section{Formula:}

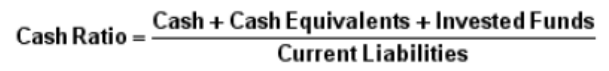

\section{Limitations of the cash ratio as a measure of liquidity}

The cash ratio is the most stringent and conservative of the three short-term liquidity ratios (current, quick and cash). It only looks at the most liquid short-term assets of the company, which are those that can be most easily used to pay off current obligations. It also ignores inventory and receivables, as there are no assurances that these two accounts can be converted to cash in a timely matter to meet current liabilities (Charles. T, 2004)

However, very few companies will have enough cash and cash equivalents to fully cover current liabilities, which isn't necessarily a bad thing.

The cash ratio is seldom used in financial reporting or by analysts in the fundamental analysis of a company. It is not realistic for a company to purposefully maintain high levels of cash assets to cover current liabilities. The reason being that it's often seen as poor asset utilization for a company to hold large amounts of cash on its balance sheet, as this money could be returned to shareholders or used elsewhere to generate higher returns. While providing an interesting liquidity perspective, the usefulness of this ratio is limited (Conroy, 2005)

\section{Importance of liquidity in an organization}

Financial managers have a lot of important reasons for which their enterprises should strive to maintain a sufficient level of liquidity.

According to Kim (1998), such reasons may be classified into 3 main groups, namely; 


\section{Necessity of current expenses financing (transaction reasons)}

Financial liquidity on sufficient level enables prompt fulfillment of the company's day to day operational obligations. Note that, every company has got several stake holders who liaise with it on daily basis and therefore interested in knowing its liquidity position in order to transact with it effectively. For example, employees have interest in the liquidity to know whether the company can meet its employees' related obligations; salaries, pension, provident fund e.t.c, suppliers of credit, services and goods will also check the liquidity of the company before providing such. Therefore, there is always a need for the company to maintain a sufficient degree o liquidity so as to meet such obligations and hence enhancing its reputation in the eyes of the stake holders (Kimberly. A, 2009)

\section{Necessity of financing future investment opportunities (speculative reasons)}

The level of liquidity that exceeds the daily transaction demand provides the organization with an option to take up any un expected profitable future investment opportunities that may arise (Washam, 1989; Beck, 1993). Such opportunities may include investment in financial securities such bonds, treasury bills e.t.c , especially when the interest rates are high. This may help increase the company's level of profits and liquidity.

\section{Necessity of financing future uncertainties (precautionary reasons)}

Companies need sufficient liquidity (real balances) for use in contingencies. As receipts and payments cannot be perfectly foreseen, a company should hold sufficient balances to minimize the potential loss that may arise from a contingency.

\section{Relationship between budgeting and liquidity}

To ensure liquidity, organizations need to optimally and rationally allocate funds within the organization. However, proper allocation of resources requires effective budgeting. This implies that effective budgeting leads to efficient allocation of resources, which in turn leads enhanced liquidity of an organization (Saleemi, 2001)

Planning is one of the most important tools of management. For an organization to be successful, managers need to plan. By their nature, budgets are essentially formalized plans of management's intended actions and desired results. This implies that poorly prepared budgets can spur managers into taking wrong actions which may be detrimental to the liquidity position of the organization (Stoner, 1996).

According to Marie (2001), monitoring and performance are positively related, but also budgeting and monitoring are synonymous. This implies that effective budgeting leads to effective financial monitoring which ultimately leads enhanced liquidity.

\section{Conclusion}

In the fore gone analysis attempts have been done to define budgeting according to the different authors. It is also shown that, though budgets are important tools in directing attention towards organizational goals and objectives, they may not succeed if an effective budget process (system) is not in place. In this respect, the major stages of budgeting have been highlighted plus the necessary conditions of an effective budget process. From the review it is also shown that the choice of the budgeting technique used may have a far reaching financial implication on the organization. Therefore the various approaches to budgeting have been highlighted plus their implications.

Finally, the existing literature on the definitions and measures (indicators) of liquidity plus their limitations has been presented. Attempts have also been done to bring out the possible relationship between budgeting and liquidity. 
South American Journal of Management

Special Edition 2016

\section{Methodology}

\section{Introduction}

This chapter presents methods that were used to gather data upon which presentation and analysis was based. It clearly outlines the research designs that were used, study population, sampling techniques, sources and data collection methods and data processing and analysis techniques.

\section{Research design}

Descriptive and Associational research designs were used in the study;

Descriptive research design: - this simply portrays a profile of an event of a situation /or phenomena. It was used to obtain information concerning the current status of the phenomena and hence describing the nature of the phenomena in respect to the variables under study.

Associational research design was also used to help in establishing whether there's a relationship between the dependent and independent variables.

\section{Study population}

The sample population comprised of 45 respondents consisting of the Executive Director, Six (6) Heads of department, Twelve (12) Project Managers and Administrators, Six (10) Project Assistants, and Sixteen (16) subordinate staff.

\section{Sampling}

\section{Sampling design and procedure}

Purposive sampling was used in selecting those respondents who were considered to be key informants in the study because of the role they play in the budgeting process. It was used in selecting respondents such as top administrators, heads of departments and project Managers

Simple random sampling was also used to select the respondents from a list of subordinates. Here, a subset of subordinates was chosen randomly, with each subordinate having the same chances of being chosen as a respondent.

\section{Sample size}

This is represented in the table below;

Table 2: Sample size of respondents

\begin{tabular}{|l|c|c|}
\hline \multicolumn{1}{|c|}{ Category } & $\begin{array}{c}\text { Targeted Number } \\
\text { of respondents }\end{array}$ & $\begin{array}{c}\text { Actual Number of } \\
\text { respondents }\end{array}$ \\
\hline Executive Director & 1 & 1 \\
\hline Heads of Department & 6 & 4 \\
\hline Project Managers & 12 & 10 \\
\hline Project Assistants & 10 & 7 \\
\hline Subordinate staff & 16 & 16 \\
\hline Total & 45 & 38 \\
\hline
\end{tabular}

\section{Sources of data}

Both primary and secondary data were used to enable the collection of proper, relevant and comprehensive data.

\section{Primary data}

This is the type of data collected for the first time. Such information was obtained through use of questionnaires directly from the employees of Infectious Diseases Institute 


\section{Secondary data}

This type of data already existed and was available to be used by the researcher. It was obtained through reviewing the existing literature on budgeting and Liquidity from various text books, research reports, internet, journals and financial records of Infectious Diseases Institute

\section{Data collection methods and instruments}

\section{Questionnaires}

This is a written or printed form of questions used in gathering or extracting specific information from respondents. Both structured and semi - structured questions were used in this study. To increase response and compliance, the questionnaires were simply worded, relatively short but comprehensive.

\section{Interviews}

Interviews were also conducted in order to get detailed data from the top administrators and a few of the subordinate staff with the help of interview guides.

\section{Data processing and Analysis}

Data processing in this study involved preparation of raw data for analysis by editing, coding and classification of data. Specific attention was put on only completed questionnaires by selected respondents in this study.

The processed data was then analyzed using SPSS technique, in order to measure the significant relationship between the two variables.

\section{Data presentation, interpretation and discussion}

\section{Introduction}

This chapter presents findings of the study in reference to the research objectives and questions that were presented in chapter one, plus their interpretations and discussion. Findings were based on a total of 38 respondents that were approached. Though 45 respondents were initially targeted, the researcher registered some cases of non - compliance. In this chapter, attempt was also made to relate the findings to the existing literature, so as to establish points of agreement and disagreement. This chapter however, begins with a brief look at the sample characteristics that were considered relevant for the study.

\section{Sample-characteristics}

\section{Gender of respondents}

Reflecting the gender of respondents, the majority were male as shown in the table below;

Table 3: Gender of respondents

\begin{tabular}{|l|l|l|l|l|}
\hline \multirow{2}{*}{$\begin{array}{l}\text { Category of } \\
\text { respondents } \\
\text { frequency }\end{array}$} & \multicolumn{2}{|c|}{ Male } & \multicolumn{2}{c|}{ Female } \\
\cline { 2 - 5 } & frequency & percentage & frequency & Percentage \\
\hline Executive Director & 1 & $100 \%$ & 0 & $0 \%$ \\
\hline Heads of department & 3 & $75 \%$ & 1 & $25 \%$ \\
\hline Project Managers & 7 & $70 \%$ & 3 & $30 \%$ \\
\hline Source: primary data & &
\end{tabular}

\section{Level of Education}

Table 4: level of education

\begin{tabular}{|l|l|}
\hline Category of & Qualification \\
\hline
\end{tabular}


South American Journal of Management

Special Edition 2016

\begin{tabular}{|l|c|c|c|l|}
\hline respondents & Diploma & Degree/Equivalent & Masters/Phd & Others \\
\hline $\begin{array}{l}\text { Executive Director } \\
\text { Top management }\end{array}$ & - & - & $1(100 \%)$ & \\
\hline $\begin{array}{l}\text { Heads of } \\
\text { department }\end{array}$ & - & - & $4(100 \%)$ & \\
\hline Project Managers & - & - & $10(100 \%)$ & \\
\hline Project Assistants & - & $6(86 \%)$ & $1(14 \%)$ & \\
\hline Subordinate staff & $2(12 \%)$ & $14(88 \%)$ & & \\
\hline \multicolumn{5}{|l}{ Source: primary data } \\
\hline
\end{tabular}

As shown in the table above, the Executive director, all Departmental Heads and project managers hold a minimum qualification of a Masters degree. The majority of the project assistants and surbodinate staff hold degrees in their respective fields and only 2 represented by $12 \%$ hold diplomas.

\section{Work experience of the respondents}

Table 5: work experience of the respondents

\begin{tabular}{|l|c|c|c|c|}
\hline Category & $\begin{array}{c}\text { Less than } 2 \\
\text { years }\end{array}$ & $2-5$ years & $6-10$ years & $\begin{array}{c}\text { More than } 10 \\
\text { years }\end{array}$ \\
\hline Executive Director & $1(100 \%)$ & & & \\
\hline Heads of department & $1(15 \%)$ & $3(75 \%)$ & & \\
\hline Project Managers & $4(40 \%)$ & $6(60 \%)$, & & \\
\hline Project Assistants & $3(43 \%)$ & $4(57 \%)$ & & \\
\hline Subordinate staff & $5(31 \%)$ & $7(44 \%)$ & $4(25 \%)$ & \\
\hline Source: primary data
\end{tabular}

The table above indicates that the majority of top senior management had served the institution for more than 2 years. On the other hand, the majority of the project Managers and assistants plus surbodinate staff had served for a period of more than 2 years. Over all, only 14 out of the 38 respondents, representing 37\% had served for a period of less than 2 years. Basing on the assumption that the longer the length of the period, the more knowledgeable one becomes about something, the respondents were therefore considered knowledgeable in the major issues concerning budgeting and the liquidity levels within the institute. This shows that data obtained from an overwhelming majority of respondents was elicited from an informed point of view. The data can therefore be regarded as reliable.

\section{Departmental representation of respondents}

Questionnaires were distributed in various departments for both categories of respondentsThey were represented as indicated in table 6 below; 39

Table 6: Departmental representation of respondents

\begin{tabular}{|l|c|c|c|c|}
\hline Department/section & $\begin{array}{c}\text { Heads of } \\
\text { department }\end{array}$ & $\begin{array}{c}\text { Project } \\
\text { Managers }\end{array}$ & Other Staff & Total \\
\hline Director's Office & 1 & & & $1(3 \%)$ \\
\hline $\begin{array}{l}\text { Finance and } \\
\text { Administration }\end{array}$ & 1 & - & 6 & $7(18 \%)$ \\
\hline $\begin{array}{l}\text { Strategic Planning \& } \\
\text { Development }\end{array}$ & 1 & - & 5 & $6(16 \%)$ \\
\hline Outreach Department & 1 & 5 & 4 & $10(26 \%)$ \\
\hline Research Department & - & 3 & 2 & $5(13 \%)$ \\
\hline Training Department & 1 & 2 & 2 & $5(13 \%)$ \\
\hline $\begin{array}{l}\text { Prevention, Care \& } \\
\text { Treatment (PCT) }\end{array}$ & - & - & 3 & $3(11 \%)$ \\
\hline
\end{tabular}




\begin{tabular}{|l|c|c|c|c|}
\hline Total & 5 & 10 & 23 & $38(100 \%)$ \\
\hline Source: primary data
\end{tabular}

Findings on the appropriateness of budgeting process (system) conducted in Infectious Diseases Institute

As already noted, a sound and effective budgeting system is based upon certain prerequisites/or conditions. Failure to observe and appreciate these essentials will render the budgeting exercise ineffective (Arora, 1995). It was against this background that one of the objectives was to evaluate the budgeting process (system) conducted in the institution. In pursuing the above objective, 3 major conditions were considered; that is, Employee participation in the budgeting process, Communication of the details of the budget activities, Continuous budget monitoring and review.

Findings to each of the above conditions are presented in the proceeding discussion

\section{Employee participation in the budgeting process}

Any control system, including budgetary control should be accepted by the people who operate it; otherwise they tend to obstruct the flow of information hence making the system ineffective (Pandey, 1994; Arora, 1995).

It was in light of this that the respondents were asked to indicate whether they were involved in budget formulation. The responses were as indicated in table 7 below;

Table 7: Employee participation in the budget process

\begin{tabular}{|l|l|l|}
\hline Value label & Frequency & Percentage \\
\hline Yes & 25 & $66 \%$ \\
\hline No & 10 & $26 \%$ \\
\hline No response & 2 & $5 \%$ \\
\hline Spoilt & 1 & $3 \%$ \\
\hline Total & 38 & $100 \%$ \\
\hline \multicolumn{2}{|l|}{ Source: primary data } \\
\hline
\end{tabular}

From the table above, out of the 38 respondents who completed the questionnaires, $25(66 \%)$ reported their participation in the budgetary process.

Asked in what aspects they were involved, the responses were as presented in table 8 below;

Table 8: Nature of involvement in the budget setting

\begin{tabular}{|l|l|l|}
\hline Value label & Frequency & Percentage \\
\hline Provide initial estimates & 11 & $44 \%$ \\
\hline List major activities & 8 & $32 \%$ \\
\hline Consolidate dept. budgets. & 6 & $24 \%$ \\
\hline Total & 25 & $100 \%$ \\
\hline
\end{tabular}

Though a relatively higher percentage claimed to have some form of input into the budgeting process $25(68 \%)$, a further investigation into the matter revealed that, their involvement in the overall budget process was limited to provision of initial estimates as required by the heads of departments and project Managers.

In a discussion with Top management about whether subordinate staff should be involved in budget preparation, one top official had this to say;

"Ahhhhhh...not necessary, after all most of them are ignorant of what budgets are for. Additionally, a lot of time is likely to be wasted on unnecessary consultations over issues which they are less informed about". 
South American Journal of Management

Special Edition 2016

\section{Budgeting technique used within the institution}

During the survey, the respondents were asked to indicate the method they use to arrive at the final budget estimates. The responses were as indicated in table 9 below;

Table 9: budgeting techniques used

\begin{tabular}{|l|l|l|}
\hline Technique & Frequency & Percentage \\
\hline Incremental & 18 & $47 \%$ \\
\hline Zero based & 5 & $13 \%$ \\
\hline Activity based & 11 & $29 \%$ \\
\hline Others & 4 & $11 \%$ \\
\hline Total & 38 & $100 \%$ \\
\hline Source: primary data. \\
\hline
\end{tabular}

From table 9 above, out of 38 respondents who responded to this question, 18(47\%) indicated the use of incremental budgeting. This is where the previous year's estimates are used as a basis for preparing new estimates. 5(13\%) of the respondents indicated the use of zero based budgeting. Only $11(29 \%)$ reported the use of the activity based budgeting. However, some of the respondents were not sure of the budgeting technique in use.

In a further discussion with some of the top managers, as to why the incremental approach was frequently used because it seemed to receive more responses, one top official made this remark;

"normally, it is like what we are already spending as reflected in the previous budget figures is accepted as necessary. During the budget meetings, we only seem to justify increases sought above the previous year's estimates".

\section{Communication of details of the budgeting activities}

During budget preparation, the budget committee must ensure that all budget guide lines and other relevant information are made aware to those responsible for preparing budgets at all levels to avoid conflicting and incompatible departmental budget demands.

In this regard, the respondents were asked to state whether communication to this effect was adequate. The responses are indicated in the table below;

Table 10: Communication of the budgeting activities at all levels

\begin{tabular}{|l|l|l|}
\hline Value label & Frequency & Percentage \\
\hline Yes & 15 & $39 \%$ \\
\hline No & 18 & $48 \%$ \\
\hline Not sure & 5 & $13 \%$ \\
\hline Total & 38 & $100 \%$ \\
\hline \multicolumn{2}{|l|}{ Source: primary data. } \\
\hline
\end{tabular}

Out of the 38 respondents, $15(39 \%)$ reported that there is adequate communication of the budgeting details and guidelines at all levels, 18(48\%) responded negatively while 5(13\%) were not sure.

Though there is some degree of communication as evidenced by $39 \%$ of the respondents, a further probe into the matter revealed that they take long to communicate and most of the times, only a few people are communicated to. Since communication is important in budget co-ordination, poor communication may result into making incomplete budgets (Arora, 1995)

\section{Budget monitoring and review}

Budget monitoring and review requires continuous and timely flow of information for comparison of actual results against the targeted performance. Where budgets only remain in print, they are less likely to achieve their intended objectives. 
In this regard, the respondents were asked to state whether the budget committee reviewed the performance of the budget through continuous monitoring. The responses were as indicated in table 11 below;

Table 11: Monitoring the performance of the budget.

\begin{tabular}{|l|l|l|}
\hline Value label & Frequency & Percentage \\
\hline Yes & 25 & $66 \%$ \\
\hline No & 12 & $32 \%$ \\
\hline Not sure & 1 & $2 \%$ \\
\hline Total & 38 & $100 \%$ \\
\hline \multicolumn{2}{|l}{ Source: primary data. } \\
\hline
\end{tabular}

Table 11 above shows that, 25(66\%) of the respondents reported that the budget committee reviewed the performance of the budget through monitoring of the activities carried out. $12(32 \%)$ responded negatively while only one respondent was not sure.

It is further important that departmental heads and subordinates that are actually responsible for budget implementation are continuously given a feedback regarding actual performance. Timely feedback is important to ensure that corrective action is taken before things go out of hand. Undue delays restrict the flow of information, making monitoring and control ineffective (Belkaui, 1990). Frequent feedback has a motivational effect (Lucey, 1996).

In this regard, the respondents were asked to indicate how often they received a feed back on the actual performance as against the budgeted. The responses were as indicated $\mathrm{n}$ the table 12 below;

Table 12: Frequency of reporting

\begin{tabular}{|l|l|l|}
\hline Value label & Frequency & Percentage \\
\hline Monthly & 5 & $13 \%$ \\
\hline Quarterly & 11 & $29 \%$ \\
\hline Semi-annually & 8 & $21 \%$ \\
\hline Annually & 14 & $37 \%$ \\
\hline Total & 38 & $100 \%$ \\
\hline Source: primary data. \\
\hline
\end{tabular}

The responses above indicated that, only $13 \%$ of the respondents received the necessary feed back at least on a monthly basis, 11(29\%) receive feedback after 3 months, $8(21 \%)$ after 6 months and 14(37\%) after a year. From this, it can be seen that over $58 \%$ of the respondents receive feedback utmost after a period of 6 months. This timing is relatively too long for effective and appropriate corrective action.

Reporting of deviations against the budgeted results alone is not worth an effort unless corrective action is taken to ensure that such inefficiencies do not occur in future (Booth, 1990). In this vein, respondents were asked to indicate whether management took any corrective actions in case of any divergences from the budget estimates. The responses were as indicated in table 13 below;

Table 13: Corrective actions taken if adverse variances are reported.

\begin{tabular}{|l|l|l|}
\hline Value label & Frequency & Percentage \\
\hline Yes & 24 & $63 \%$ \\
\hline No & 12 & $32 \%$ \\
\hline Not sure & 2 & $5 \%$ \\
\hline Total & 38 & $100 \%$ \\
\hline Source: primary data \\
\hline
\end{tabular}


South American Journal of Management

Special Edition 2016

24 respondents, representing $63 \%$ indicated that corrective actions are taken in case of adverse deviation from the budget estimates. However, a further probe into the nature of actions taken indicated that, where as there is continuous revision of the budgets; it is done without a thorough investigation into the possible causes of the deviations. This greatly hampers the usefulness of budgets as control tools.

During the survey, respondents were further asked to comment on the adequacy of budget monitoring and control in the institution. The following responses were received;

Table 14: perceived extent of budget monitoring and control

\begin{tabular}{|l|l|l|}
\hline Value label & Frequency & Percentage \\
\hline Inadequate & 19 & $50 \%$ \\
\hline Adequate & 11 & $29 \%$ \\
\hline Excellent & 8 & $21 \%$ \\
\hline Total & 38 & $100 \%$ \\
\hline \multicolumn{2}{|l}{ Source: primary data } \\
\hline
\end{tabular}

The responses in table 14 above show that budget monitoring and control was perceived as inadequate by $50 \%$ of the respondents. Only $29 \%$ felt it was adequate. $21 \%$ of the respondents indicated that budget monitoring was excellent

\section{Findings on the level and trend of liquidity}

During the study, the respondents were asked to rate the current level of liquidity in the institution. The responses were as indicated in the table 15 below;

Table 15: level of liquidity in the Institution

\begin{tabular}{|l|l|l|}
\hline Value Label & Frequency & Percentage \\
\hline Very High & 1 & $3 \%$ \\
\hline High & 7 & $18 \%$ \\
\hline Moderate & 10 & $26 \%$ \\
\hline Low & 18 & $47 \%$ \\
\hline Very Low & 2 & $6 \%$ \\
\hline Total & 38 & $100 \%$ \\
\hline \multicolumn{2}{|l}{ Source: primary data } \\
\hline
\end{tabular}

From the table above, out of the 38 respondents, only $1(3 \%)$ rated the level of liquidity as very high, $7(18 \%)$ rated it as High, while $19(26 \%)$ rated it as moderate. A bigger number of respondents rated it as low, that is; $18(47 \%)$ and $2(6 \%)$ as very low.

\section{Trend of liquidity levels in the Institution}

In this regard, the respondents were asked to state whether they had noticed any changes in the liquidity levels of the institution over the past 4 years. The responses were as indicated in table 16 below;

Table 16: Changes in liquidity levels

\begin{tabular}{|l|l|l|}
\hline Value label & Frequency & Percentage \\
\hline Yes & 36 & $95 \%$ \\
\hline No & 0 & 0 \\
\hline Not sure & 2 & $5 \%$ \\
\hline total & 38 & $100 \%$ \\
\hline Source: primary data \\
\hline
\end{tabular}

Table 16 above shows that, $36(95 \%)$ of the respondents reported that they had noticed changes in the liquidity levels of the institution over the past 4 years. Only $2(5 \%)$ of the respondents were not sure and none of them responded negatively. 
During the survey, respondents were requested to state the nature of trend. The following responses were received

Table 17: Trend of liquidity levels in the institution

\begin{tabular}{|l|l|l|}
\hline Value Label & Frequency & Percentage \\
\hline Increasing & 7 & $18 \%$ \\
\hline Decreasing & 29 & $76 \%$ \\
\hline Not sure & 2 & $6 \%$ \\
\hline Total & 38 & $100 \%$ \\
\hline \multicolumn{2}{|l}{ Source: primary data } \\
\hline
\end{tabular}

From table 17 above, out of the 38 respondents who responded to this question, 29 (76\%) reported that the liquidity levels have been decreasing over years and only $7(18 \%)$ reported that the levels have been increasing over the 4 year period.

In this regard, the respondents were further requested to give responses to a number of items that represented possible causes of the declining trend in the liquidity levels of the institution over the past 4 years. The items were scored on a 5-point likert scale with responses ranging from strongly agree to strongly disagree. The perception of the respondents is indicated in table 18 below;

Table 18: possible causes of declining trend in liquidity levels

\begin{tabular}{|c|c|c|c|c|c|c|c|c|c|c|c|c|}
\hline \multirow{3}{*}{ Items } & \multicolumn{12}{|c|}{ Rating $(\mathrm{N}=29)$} \\
\hline & \multicolumn{2}{|c|}{ SA } & \multicolumn{2}{|c|}{ A } & \multicolumn{2}{|c|}{ NS } & \multicolumn{2}{|c|}{$\mathrm{D}$} & \multicolumn{2}{|c|}{ SD } & \multicolumn{2}{|c|}{ TOTAL } \\
\hline & $f$ & $\%$ & $f$ & $\%$ & $f$ & $\%$ & $f$ & $\%$ & $f$ & $\%$ & $f$ & $\%$ \\
\hline $\begin{array}{l}\text { Inconsistency in } \\
\text { following the budget } \\
\text { estimates }\end{array}$ & 6 & 21 & 11 & 38 & 4 & 14 & 5 & 17 & 3 & 10 & 29 & 100 \\
\hline $\begin{array}{l}\text { Insufficient liquidity } \\
\text { monitoring and } \\
\text { Management }\end{array}$ & 5 & 17.2 & 8 & 27.6 & 4 & 13.8 & 8 & 27.6 & 4 & 13.8 & 29 & 100 \\
\hline Limited Donor funding & 13 & 44.8 & 9 & 31 & 2 & 6.9 & 4 & 13.8 & 1 & 3.4 & 29 & 100 \\
\hline Average & 8 & 27.7 & 9.3 & 32.2 & 3.3 & 11.6 & 5.6 & 19.5 & 2.6 & 9.06 & 29 & 100 \\
\hline
\end{tabular}

Abbreviations: $f$ - frequency, \%- percentage, SA - Strongly Agree, A- Agree, NS- Not Sure, D- Disagree, SD- Strongly Disagree

Source: primary data

Table 18 summarizes the way respondents reported on the possible causes of the declining liquidity levels in Infectious Diseases Institute. On average, over $27.7 \%$ /or $32.2 \%$ of the respondents agreed /or strongly agreed with the listed items as causes of trend, though the magnitude varies from one alternative to another. Results show that inconsistency in following the budget estimates and limited donor funding, are the most plausible since each factor has respondents above the average to justify the fact

\section{Establishing the relationship between budgeting and the liquidity level}

Table: 19 Correlation between budgeting and the liquidity levels

\begin{tabular}{|l|l|l|l|}
\hline \multirow{5}{*}{ Budgeting } & & Budgeting & Liquidity level \\
\cline { 2 - 4 } & Pearson Correlation & 1.000 & .570 \\
\cline { 3 - 4 } & Sig. (2-tailed) & & .002 \\
\cline { 3 - 4 } & $\mathrm{N}$ & 38 & 38 \\
\hline Liquidity level & Pearson Correlation & .570 & 1.000 \\
\cline { 3 - 4 } & Sig. (2-tailed) & .002 & \multirow{2}{*}{37} \\
\cline { 3 - 4 } & $\mathrm{N}$ & 37 & 37 \\
\hline
\end{tabular}


From the table 19 above, results indicated that there is a positive and significant relationship between budgeting and liquidity level at Pearson correlation coefficient

$\mathrm{r}=0.570^{* *}$. This implies that, over $32 \%$ of the variations in the liquidity levels between 2010 and 2014 were caused by budgeting. The results therefore show consistence with the observations made by such scholars as Gutsi (2002), Johnson (1982), Novik (1973) and Miller (1982). Each of these scholars has noted that budgeting is central in influencing the level of liquidity in an organization.

Similar views were given by some of the selected top administrators. When asked whether the declining level of liquidity in the institution could be attributed to the way budgeting is conducted, one top official responded as follows;

"there is no way an organization can operate efficiently without following a budget. We use budgets to identify our cash requirements so as to optimize our sources of funding / or minimize on our expenses if possible. So, any form of financial achievement has to be as a result of the budget we follow. To assume otherwise is to be unrealistic..."

It must be noted that although budgeting was found to be significantly accountable for the decline in the variations of liquidity levels at Infectious Diseases Institute for the last 4 years, it was not the only factor. If it was, the coefficient of correlation would be perfect (that is $r=$ 1.00). However, results show that " $r$ " was less than one (that is, $r=0.570$ ). This shows that other factors were also at play.

This was supported by some of the top administrators that the researcher interacted with. Asked whether budgeting was the factor causing the decline in the liquidity level, one of them responded negatively attributing the cause to other factors. He had this to say;

"The budgeting is okay, but the problem is inflation. At times, the price of the budgeted inputs turn out to be higher than those that were prevailing at the time of budgeting, you are forced to

Spend more than the budgeted"

.In general therefore, although budgeting was greatly found to be accountable for the decline in liquidity levels for the last 4 years, further investigations show that it was not the only factor in the whole game.

\section{Summary of findings, conclusions and recommendations}

\section{Introduction}

Having presented, analyzed and interpreted the research findings, this chapter presents a summary of the major research findings, conclusions drawn from the study, recommendations and suggestions for further research.

\section{Summary of the major findings}

\section{Findings on the appropriateness of the budgeting process (system) conducted}

The findings indicated that the budgeting process was not appropriate. This was because some of the essential practices that ought to be observed during budget formulation were found to be highly under mined. For example;

The findings showed that, though a good number of subordinate staff reported some level of involvement in budget formulation, their participation was negligible since it was limited to provision of initial estimates to the departmental heads rather than contribution of ideas to the making of the budgets. The results also indicated that there was poor communication of the budgeting activities at all levels of the institution.

Findings also revealed that, there was apparently poor information feedback regarding deviations from the budget estimates. Reports showing actual results against the budgets take too long a time for any immediate and effective corrective action. Even when deviations are reported, little effort is taken to investigate the causes of such deviations. 
Despite the changes that necessitate organizations to adopt new ideas and better ways of budget management, results indicated that the institution is still preoccupied with the traditional incremental budgeting approach, and the overall budgetary process is regarded as another of the routine tasks to be performed.

\section{Findings on the level and trend of liquidity}

The findings indicated that the current level of liquidity is low and therefore not sufficient to run the operations on the institution effectively and efficiently. It is also clearly indicates that, the liquidity levels have been decreasing over the past 4 years. Therefore, if such a trend persists, it is likely to impact greatly on the future operations of the Institution.

\section{Findings on the relationship between budgeting and liquidity}

From the analysis made in table 19, the results indicated that there existed a significant positive relationship between budgeting and liquidity levels $(r=0.570)$. This implies that, an appropriate and effective budgeting system will lead to higher levels of liquidity. On the other hand, a poor and inappropriate budgeting system will result in a tremendous decline in liquidity levels. This therefore seals the relevance of budgeting in enhancing the liquidity levels and thus, care should always be taken in choosing the most appropriate and effective budgeting system.

\section{Conclusions}

From the results presented and discussed in the previous chapter, the following conclusions can be reached.

In response to research question one: - the results clearly show that the level of employee participation in the budget setting process is very minimal, communication of the budgeting activities at all levels of the institution is poor and the level of information feedback regarding deviations from the budget estimates is inadequate. In light of this, it can be concluded that the budgeting process was not appropriate.

Results further reveal that the traditional practice of using historical cost information to estimate budget requirements is prevalent. Managers only have to justify increases above the previous budgets. Though this approach has been supported on its case of use and the relatively low level of detail expected from users, it has resulted into inefficiencies being continued year after year, since it merely involves extrapolation of the past. This has greatly constrained the appropriateness and effectiveness of the budgeting system within the institution.

However, despite top management's awareness of the problems associated with this technique of budgeting, no efforts have been made to adopt better and more efficient techniques.

In response to research question two: - the results indicated that the level of liquidity is low and since liquidity forms the working capital of any organization, efforts should be taken by management to curb this trend in order to rescue the future operations of the Institution

Regarding research question three: - findings indicated that there exists a significant positive relationship between budgeting and the liquidity performance of the institution. Given the weaknesses in the budgeting system of the institution, it is concluded that budgeting was therefore held accountable for the declining levels in liquidity between 2010 and 2014. However, an effort made towards rectifying the weaknesses in the budgeting system used would highly improve the liquidity performance of Infectious Diseases Institute.

\section{Recommendations}

The following recommendations are made basing on the conclusions reached in the previous section.

In view of the results obtained in response to research questions, it is recommended that; 
South American Journal of Management

Special Edition 2016

The budgeting committee should encourage collective efforts, co-operation and active participation of all employees all through the budgeting process. This will help tap different ideas from all members of the institution, motivate them work more effectively, and thereby improving the budgeting process.

Proper and adequate communication of the budgeting activities should be made at all levels to allow easy flow of information between departments. The final budgets should not necessarily be what top administrators think, but should also consider what other subordinates believe is feasible. This should be aimed at improving budget acceptance as well as commitment to the overall organizational goals and objectives.

There is need to improve the information feedback on how the actual results are progressing compared with the budgeted. Budget monitoring and reporting should therefore be timely, clear and comprehensive. Significant variances should be brought to the attention of management to take control before any adverse results get much worse.

A new approach of budgeting which encourages improvement by eliminating inefficiencies and wasteful expenditure should be adopted. A case in point for example, is the Activity based budgeting (ABB). In contrast to the incremental approach, ABB builds budgets on the basis of activities to be carried out by each cost centre rather than an extrapolation from historical inputs.

\section{Areas for further research}

Findings show that budgeting is not the only factor responsible for the declining liquidity levels in the institution. Therefore,

A comprehensive study is needed to establish other factors causing such poor liquidity levels at Infectious Diseases Institute / or other related institutions.

The study was basically centered on the effect of budgeting on the liquidity performance in Infectious Diseases Institute. A similar study can be conducted on how budgetary implementation and control affects such performance.

\section{References}

[1.] Arora, M. N (1995), Cost Accounting principles and practice, Vikas Publishing House.

[2.] Amanya, J (1999), Determinants of an effective budgetary process in selected public enterprises in Uganda.

[3.] Balunywa, W (1997), Business Management.

[4.] Biggs, C and Benjamin (1990), Management Accounting Techniques, CIMA Publication.

[5.] Bellis, J (1991), Activity based cost management, Management Accounting Hand book, CIMA.

[6.] Clive, Otley and Merchant (1995), Accounting for Management Control. Chapman and Hall publishers.

[7.] Drury, C (1992), Management and Cost Accounting, Chapman Publishers.

[8.] Fozzard, A (2001). The basic budgeting problem: Approaches to resource allocation in the public sector and their implications for pro-poor budgeting. Kampala: Centre for Aid and public expenditure.

[9.] Grace, C.E (1964), Management Controls, Mitchell and co. New York.

[10.] Hay, L. E, and Engstron, J. H. (1987). Essentials of Accounting for government and_non-profit making organizations, Home Wood: Irwin

[11.] Horngren, C. T (1993), Introduction to management Accounting. Prentice Hall.

[12.] Jonsson, S (1982). "Budget behaviour in Local government", Accounting organizations and society, 3(7)

[13.] Lyden, J. and Miller, E. G. (1982), Public budgeting - Program planning and Implementation (4th ed). Prentice - Hall.

[14.] Miller, E. C (1996), Objectives and Standards: An approach to planning and control, AMA. Research study 74 .

[15.] Modern, J (1986), Zero based budgeting. Management Accounting.

[16.] Novik, D. (ed) (1973). Current practice in programme budgeting (PPBS). New York: Crane Russak. 
[17.] Otley, D (1976), Budgeting control and Managerial performance, unpublished.

[18.] Otley, D (1978), Budget use and managerial performance. Journal of Accounting Research, Vol. 16. No 1.

[19.] Pandey, I. M (1996), Management Accounting. Vikas Publishing House.

[20.] Stoner, J (1996), Management, Prentice Hall.

[21.] Suver, J and Brown (1977), Where does_zero based- budgeting work? Harvard Business review, Nov/Dec.

[22.] Kakuru Julius (2000), Finance decisions and the business, 1st Edition, kampala, Business publishing group.

[23.] Charles Tapiero (2004), Risk and Financial Management: Mathematical and computational methods.

[24.] John Wiley (2004), Business Trends Quarterly and their risk involvement

[25.] Conroy (2005), "Customer profitability, and treatment of Acquisition spending", Journal of Managerial Issues, 17 (1), $11-25$ 